\title{
CARBON ISOTOPE FLUCTUATIONS IN PRECAMBRIAN MARBLES OF THE SERIDÓ BELT, BORBOREMA PROVINCE, NORTHEAST BRAZIL
}

\author{
RIELVA SOLIMAIRY CAMPELO DO NASCIMENTO* AND ALCIDES NOBREGA SIAL
}

\begin{abstract}
Carbon isotope chemostratigraphy is a powerful tool in the study of non-fossiliferous metasedimentary carbonate rocks. This study deals with $\mathrm{d}^{13} \mathrm{C}$ fluctuation within the Precambrian Jucurutu and Seridó Formations, Borborema province, in northeastern Brazil whose age has been a matter of debate for over three decades. While some researchers have assumed a Paleoproterozoic age for both Formations, radiometric ages have raised the possibility that they are Neoproterozoic. In an attempt to contribute to this debate, a detailed carbon isotope chemostratigraphy of these two Formations have been undertaken. The Jucururu Formation displays a remarkable homogeneous composition of $\delta^{13} \mathrm{C}$ with values varying from +8.5 to $+10 \%$ pDB. The Seridó Formation, by its turn, shows a more pronounced variation with, values varying from +6.5 to $+10.5 \% \mathrm{O}_{\mathrm{PDB}}$ - According to our carbon isotope data versus the available $\delta^{13} \mathrm{C}$ secular variation curves, these two Formations could be either Paleoproterozoic $(2.0-2.15 \mathrm{Ga})$ or Neoproterozoic $(0.6$ to $0.65 \mathrm{Ga})$. Further $\mathrm{Sr}$ and Nd isotope studies of these carbonate sequences, coupled with more detailed field geology, are necessary to test the Neoproterozoic-age hypothesis.
\end{abstract}

Keywords: carbon isotopes, marble, Borborema province, Seridó, NE Brazil

INTRODUCTION Because the isotopic composition of seawater has changed through time and for this the isotopic composition of marine carbonates has been used for chemostratigraphic purposes. In particular, carbon, sulfur and $\mathrm{Sr}$ isotopes have proved to be very useful tools in this regard. The isotopic study of marine carbonates from several ages has allowed the reconstruction the secular ${ }^{13} \mathrm{C} /{ }^{12} \mathrm{C}$ variation trend (Kaufman and Knoll 1995, Hoffman et al. 1998). These variations are the response to global tectonic and climatic events.

In carbon chemostratigraphy it is fundamental to select samples with primary values of $\mathrm{d}^{13} \mathrm{C}$ and that have not been affected by diagenetic or metamorphic alterations. In this way, it will be possible to estimate the primary carbon isotope composition of the seawater from which carbonates have precipitated. In several Proterozoic sedimentary carbonate successions, dolomite is isotopically similar to the associated calcite, because dolomitization is syndepositional in the presence of fluids isotopically similar to the seawater (Tucker 1983, Narbonne et al. 1994). Metamorphism usually does not affect the primary carbon isotope composition of limestones. However, metamorphic events with expressive fluid circulation can promote isotopic modifications through decarbonation reactions usually in the presence of silicate minerals (Kaufman and Knoll 1995). This is usually a localized phenomenon, restrict to shear zones or metamorphic contact aureoles, easily recognizable. Therefore, the carbon isotope composition of a marble usually reflects the composition of its protolith. Hydrothermal events, weathering or metamorphism, however, easily modifies oxygen isotopes.

One of the best selective criteria to detect post-depositional carbon isotope modifications consists in the exam of covariation between $\delta^{13} \mathrm{C}$ and $\delta^{18} \mathrm{O}$. Hydrothermal alteration and weathering usually lower the $\delta^{18} \mathrm{O}$ values. $\delta^{13} \mathrm{C}$ of carbonate samples, in which $\delta^{13} \mathrm{C}$ and $\delta^{18} \mathrm{O}$ show no correlation between them, are regarded as primary ones.

In this study, we will discuss the $\delta^{13} \mathrm{C}$ chemostratigraphy of marbles from the Seridó Group, aiming at contributing to precise the age of deposition of the carbonate rocks in this belt.

\section{THE SERIDÓ BELT AND ITS GEOLOGIC EVOLUTION The}

Seridó belt encompasses a supracrustal sequence of high-temperature low-pressure metamorphic rocks (greenschist to amphibolite facies) that have a NNE trend resulted from Neoproterozoic transcurrent shear zones. These rocks overlie a Paleoproterozoic gneissic-migmatitic substratum (2.15 to $2.23 \mathrm{Ga}$; Dantas et al. 1991) that was intruded by Brasiliano granitoids of different chemical affinities (Fig. 1).

The geodynamic history of this belt has been debated for long time, especially on features related to the stratigraphy, age and geologic evolution of the supracrustal rocks. Jardim de Sa and Salim (1980) subdivided the Seridó Group into three Formations belonging to one megacycle of sedimentation, without regional unconformities: Jucurutu (lower unit, formed by paragneisses with intercalations of marbles, and calc-silicate rocks); Equador (intermediate unit, with quartzites with intercalations of conglomerates and paragneisses); and Seridó (upper unit, micaschists with subordinate intercalations of marbles and calc-silicate rocks). Jardim de Sa (1994) described augen orthogneisses (GJ intrusive in the Jucurutu and Equador Formations and, less frequently, in the Seridó Formation. Zircon $\mathrm{U}-\mathrm{Pb}$ and $\mathrm{Pb}-\mathrm{Pb}$ ages from orthogneisses (Legrand et al. 1991, Jardim de Sa et al. 1995 ) indicate crystallization in the 1.9 to $2.0 \mathrm{Ga}$ interval. If these orthogneisses represent granitoids intrusive in the Seridó Group metasediments, this time interval would have recorded the oldest deformation that affected this belt and, therefore, would represent the minimum age for the Seridó Group metasediments.

Archanjo and Salim (1986) proposed another stratigraphic subdivision for these supracrustal rocks. They subdivided these rocks into two units: the Paleoproterozoic Jucurutu Group that includes a lower vulcanosedimentary sub-unit (Jucurutu Formation), and an upper clastic sub-unit (Equador Formation). The Neoproterozoic Seridó Group metasediments (that includes a lower sub-unit composed of metaconglomerates (Parelhas Formation) and an upper sub-unit composed mainly of schists (Seridó Formation). Achanjo and Salim (1986) and Caby (1989) consider the $\mathrm{G}_{2}$ granitoids as Paleoproterozoic anorogenic plutons, intruded synchronously to the deposition of the Jucurutu Formation sedimentary rocks. Nd isotopes yielded model age for the metasedimentary rocks of the Seridó Group ranging from 1.2 to 1.6 Ga. U-Pb in detrital zircons from paragneisses of the Jucurutu Formation indicate ages from 1.75 to $2.15 \mathrm{Ga}$ for the source rocks (Van Schmus et al. 1995,1996). On the other hand, zircons from felsic rocks, interpreted as volcanic intercalations, yielded ages of $0.74 \mathrm{Ga}$ (Van Schmus 1996), and detrital zircons from the Seridó Formation, yielded an age of $0.6 \mathrm{Ga}$ (Van Schmus et al. 1999). In summary, Van Schmus and co-workers maintain a Neoproterozoic age for the Seridó belt.

CARBON ISOTOPE CHEMOSTRATIGRAPHY About 140 samples of marbles have been collected perpendicularly to the strike at a centimetric to metric scale. This sampling includes marbles from the Jucurutu Formation collected nearby the Jucurutu town and southeast of the Caico town, state of Rio Grande do Norte, and marbles from the Seridó Formation, to the north of Santa Luzia town, state of Paraiba.

Carbon and oxygen isotope analyses have been carried out at the Stable Isotope Laboratory (LABISE) of the Federal University of Pernambuco, Recife, Brazil. Powdered samples have been reacted with orthophosphoric acid at $25^{\circ} \mathrm{C}$ overnight (dolomitic or calcitic + dolomitic samples were allowed to react for three days or more). An extended reaction period was preferred instead of increasing the reaction temperature. The released $\mathrm{CO}_{2}$ gas was cryogenically cleaned and after that analyzed in a fully automated V.G. ISOTECH SIRA II dual inlet, triple collector, mass spectrometer. The precision levels for carbon and oxygen isotopic ratios are about $0.1 \%$. Results are expressed in the PDB (Peedee Belemnite) scale in $\%$.

Marbles of the Jucurutu Formation are fine to coarse-grained, predominantly calcitic, sometimes displaying a banding with alternate gray and white layers. Near the Jucurutu town, marble lenses show a $\mathrm{N} 40^{\circ} \mathrm{NE}$ foliation and are in contact with the Jucurutu paragneiss. These marbles display $\delta^{13} \mathrm{C}$ within a narrow range $(+8.3$ to +10 $\% \mathrm{o}_{\mathrm{pDB}}$ ), and an average value of $+10 \% o$ (Fig. 2a). There is no 


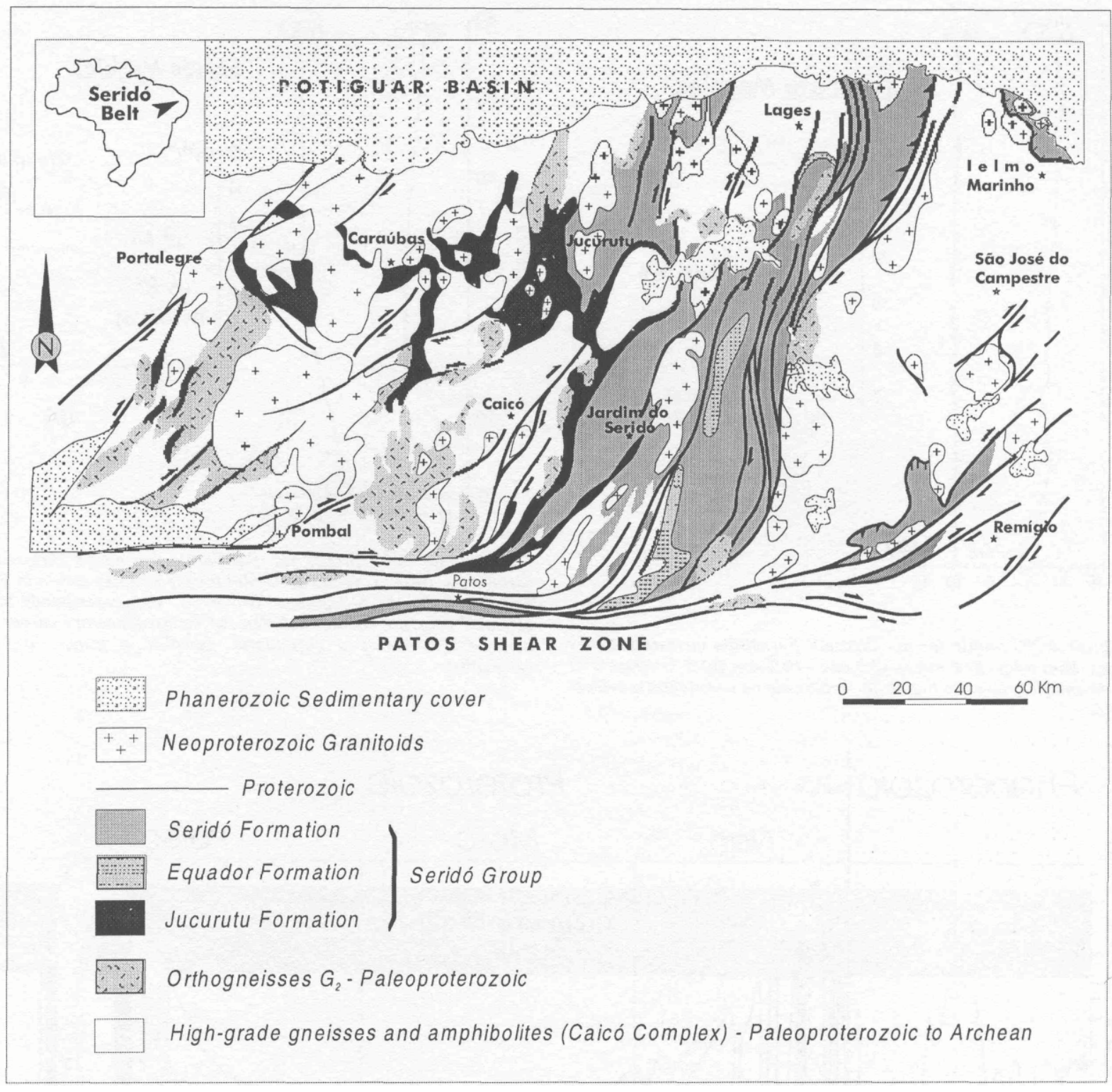

Figure 1. Simplified geologic map of the Seridó belt, Borborema province, northeastern Brazil (Jardim de Sd 1994).

substantial difference between the white and gray marble bands. Oxygen isotopes exhibit a broader variation with values ranging from -12.2 to $-5.5 \% \mathrm{O}_{\text {pdb }}$. As shown in Figure $2 b$, there is no correlation between $\delta^{13} \mathrm{C}$ and $\mathrm{d}^{18} \mathrm{O}$, indicating that the carbon isotope ratios should be, in principle, identical to those in the protolith.

The Seridó marbles appear to be more deformed than those of the Jucurutu Formation. They are usually tightly folded and found as lenses. Near the contact with micaschists, marbles exhibit xenomorphic garnet grains and sillimanite crystals usually disposed parallel to axial planes of the folds. In marbles of this Formation, $\delta{ }^{13} \mathrm{C}$ values are found in a broader range $\left(+4.4\right.$ to $+10.6 \%_{\text {OPDB }}$, Fig. $\left.3 \mathrm{a}\right)$ while $\delta^{18} \mathrm{O}$ values vary from -6.9 to $-12.6 \% \mathrm{O}_{\mathrm{PDB}}-$ Samples cluster into two groups (Fig. 3b) when $\delta^{13} \mathrm{C}$ is plotted against $\delta^{18} \mathrm{O}$, with a gap between them. There is a weak positive correlation between $8^{13} \mathrm{C}$ and $\delta^{18} \mathrm{O}$ for samples collected near the contact with biotite-schists (group a in Fig. 3b). This suggests that the carbon isotope signatures for this cluster of samples are not primary. They were probably affected by decarbonation reactions that led to the formation of $\mathrm{Ca}$-rich garnet and lowered the $\mathrm{C}$ isotope values. If these values are discarded, $8{ }^{13} \mathrm{C}$ for the Serido marbles will be restricted to the +6 to $+10.7 \% \mathrm{O}_{\mathrm{PDB}}$ interval.

DISCUSSION There are several $\mathrm{d}^{13} \mathrm{C}$ variation curves available in the literature. In this study we will adopt the $\mathrm{d}^{13} \mathrm{C}$-variation curve proposed by Hoffman et al. (1998) with minor modifications introduced by Kha et al. (1999). For the Proterozoic, this curve shows strong positive anomaly for the Paleoproterozoic in the 2.33 to $2.06 \mathrm{Ga}$ interval (Lomagundi or Jatulian event; Schidlowski et al. 1976, Melezhik et al. 1997) ascribed to the stromatolite explosion. The Mesoproterozoic is little known from the carbon isotope viewpoint and it has been kept as time interval when one had little carbon isotope ratio variation, usually around zero $\% \mathrm{O}_{\mathrm{PDB}}$ - Recent studies carried out by Kha et al. (1999) show that some carbon isotope oscillations, stronger than previously supposed, may be present between 1.5 and $1.0 \mathrm{Ga}$ age interval. The Neoproterozoic is characterized in the 0.8 to $0.54 \mathrm{Ga}$ interval by a series of successive strong oscillations, that become stronger towards the Precambrian-Cambrian boundary. The positive oscillations have been related to the increase of the organic carbon reservoir relative to the inorganic carbon reservoir, while the negative ones were caused by glacial events (Knoll et al. 1986).

The carbon isotope patterns obtained in this study have been compared to the $\delta{ }^{13} \mathrm{C}$ secular variation curve for the Proterozoic. The interval of $\delta{ }^{13} \mathrm{C}$ variation for the Jucurutu and Seridó Formations have been plotted in Fig. 4 and are represented by interval variation bands that intercept the carbon secular variation curve in three Proterozoic age intervals ( $a, b$ and $c$ in this Figure). Based on this Figure, three age intervals can be proposed:

(a) Paleoproterozoic (2.25-2.28 Ga). This age interval can be discarded because it would ascribe the Jucurutu and Seridó Formations an age older than their basement, the Caico Complex (2.23-2.15 Ga). 


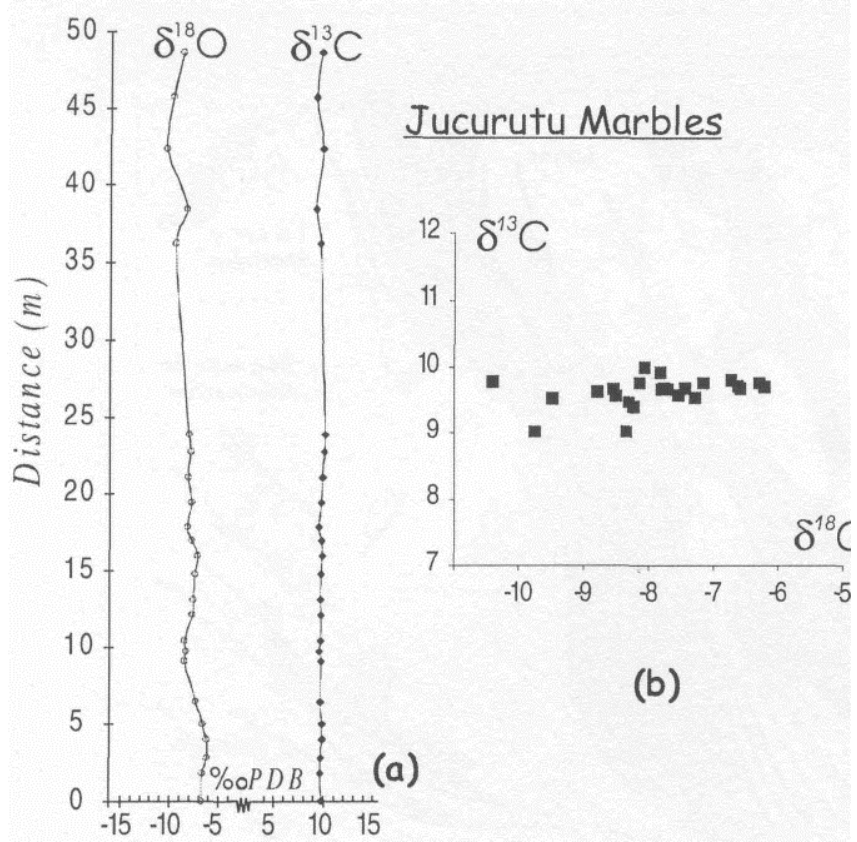

Figure 2. (a) $\delta^{13} \mathrm{C}$ profile for the Jucurutu Formation metasedimentary carbonates. Most values lie between +9.5 and $+10 \% C P D B-(b) \delta^{13} \mathrm{C}$ versus $\delta^{18} \mathrm{O}$ plot for the samples shown in Figure 2a. Apparently no correlation is evident in this plot.

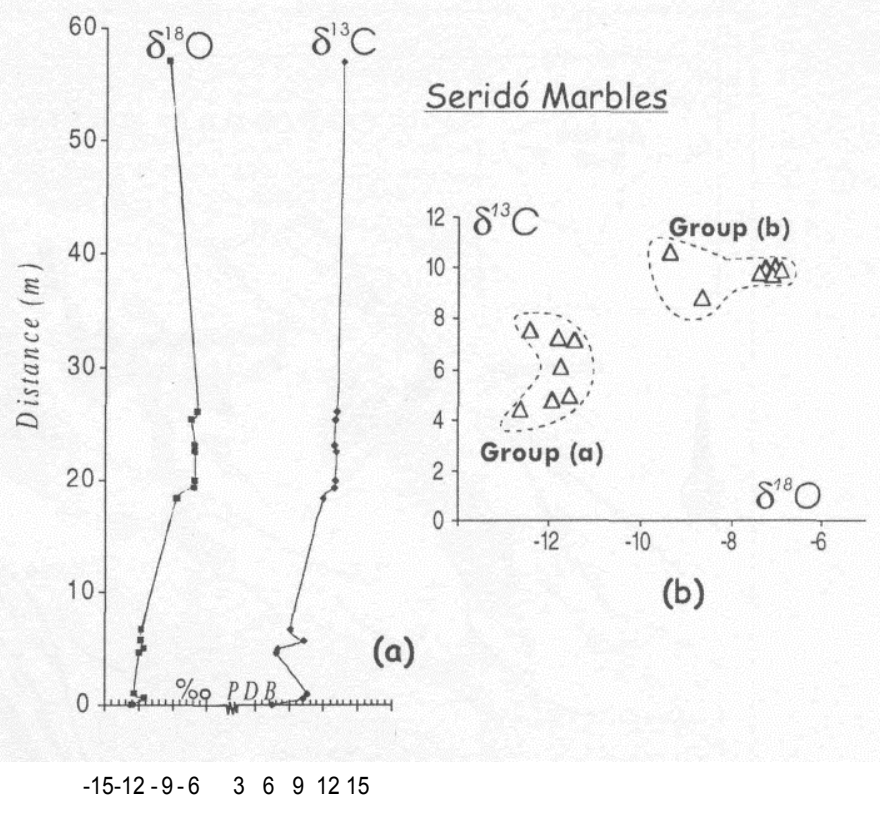

Figure 3. (a) $\delta^{13} \mathrm{C}$ profile for the Serido Formation metasedimentary carbonates, (b) $\delta^{13} C$ versus $\delta^{15} O$ plot for the samples shown in Figure $3 a$. Samples cluster in two groups. Group " $a$ " that corresponds to samples collected near the contact between the metasedimentary carbonates with biotite-schists shows a correlation. Samples in group " $b$ " show no correlation.

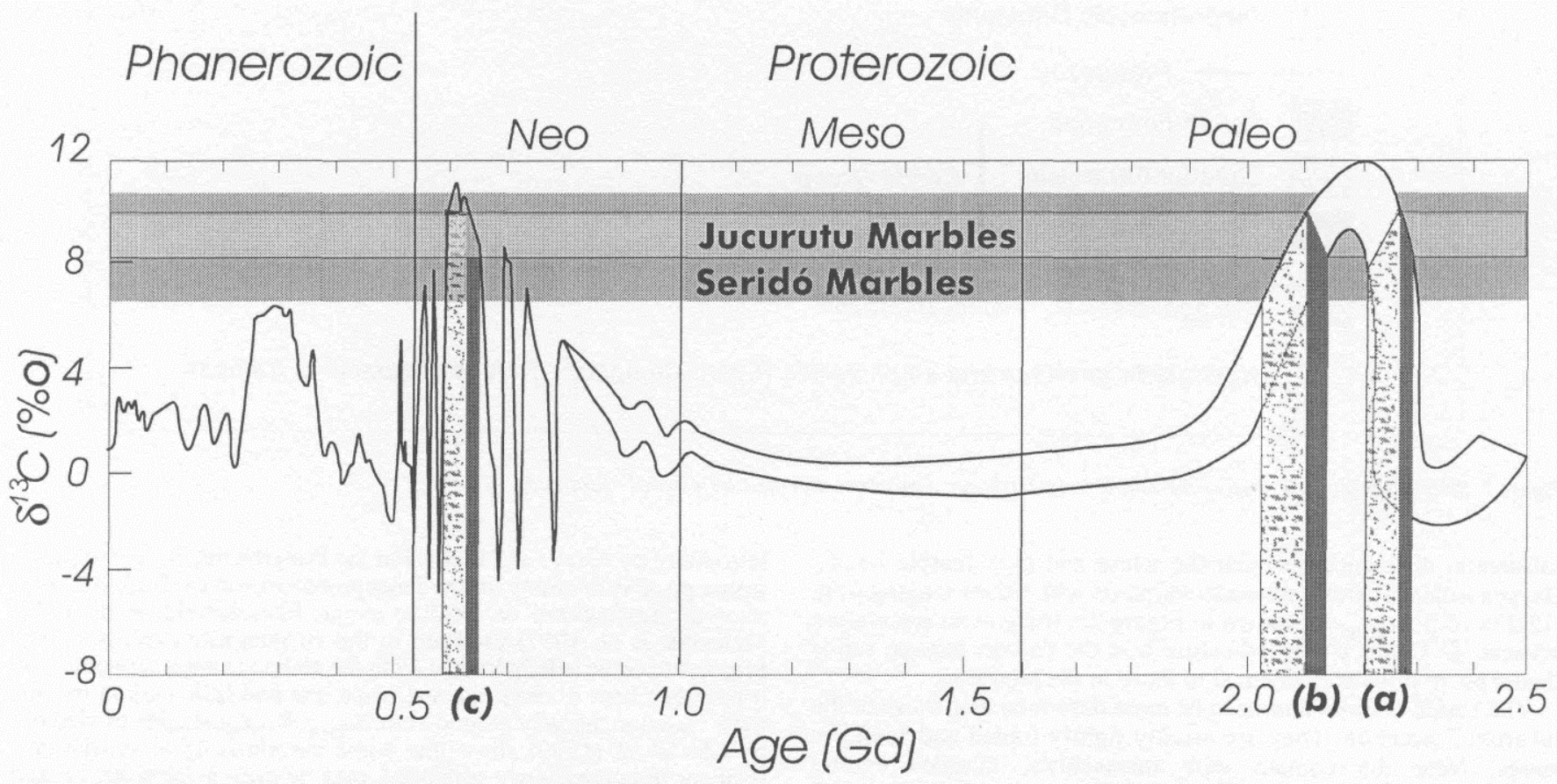

Figure 4. Secular variation in $\delta^{13} C(P D B)$ values of marine carbonates from $2.5 G$ a to the present (modified from Hoffman et al. 1998 ). The interval of variation of $\delta^{13} C$ of the Jucurutu and Seridó Formations has been indicated by horizontal gray bands, $a, b$ and $c$ indicate the probable age intervals for each of these two Formations. See text for discussion.

(b)Paleoproterozoic (2 to $2.15 \mathrm{Ga}$ ). This age interval coincides with the age interval found for orthogneisses $\left(\mathrm{G}_{2}\right)$ regarded as intrusive in the Jucurutu and Seridó Formations.

(c) Neoproterozoic (600 to $650 \mathrm{Ma}$ ). A Neoproterozoic age of $740 \mathrm{Ma}$ for the Seridó Group has been proposed by Van Schmus et al. (1996) and, more recently, an age of 600 Ma has been determined (Van Schmus et al. 1999). The hypothesis of an age of $740 \mathrm{Ma}$ would imply in $5^{13} \mathrm{C}$ values $<8 \% \mathrm{O}_{\mathrm{pDB}}$ (Fig. 4), and this conflicts with the observed C-isotope variation for the Serido metacarbonates.

If elected the 600Ma-age hypothesis, one would expect that some geological events, globally recorded, and had been registered in the
Seridó Group metasediments. For example, it is known that around $600 \mathrm{Ma}$, an important glacial event (Varanger) was globally observed. This event has been recorded by diamictites above which sedimentary carbonate displays well pronounced negative $5^{13} \mathrm{C}$ values. Such features have not been yet observed in our field and isotopic data.

CONCLUSIONS From this carbon isotope investigation, it seems reasonable to assume that the Jucurutu and Seridó carbonate rocks were deposited during the same sedimentation cycle. Although the age inferences based on carbon isotope patterns, here discussed, are not conclusive, the current data associated to the available information on the regional geology seem to favor a Paleoproterozoic age for the Seridó Group. Further Sr and Nd isotope chemostratigraphic studies of 
these carbonate sequences would allow to definitely discard the Neoproterozoic-age hypothesis.

Acknowledgements: This study is part of R. S. C. Nascimento's doctoral thesis, under development. We want to express our gratitude to Victor Hugo Santos and Anil Maheshwari for their colaboration during the field work. R. S. C. Nascimento also wants to thank E. F. Jardim de Sa for discussions on the regional geology of the Borborema province. This is the NEG-LABISE contribution $\mathrm{n}$. 170. To two anonymous referees of RBG for the critical review of the manuscript.

\section{References}

Archanjo C.J. \& Salim J. (1986) Posição da Formação Seridó no contexto estratigráfico regional (RN-PB). In: Simp. Geol. Nordeste, 12, SBG, João Pessoa, 270-281.

Buick R., Des Maraes D.J., Knoll A. H. (1995) Stable isotopic compositions of carbonates from the Mesoproterozoic Bangemall Group, northwestern Australia. Chem. Geology. 123:153-171.

Caby R. 1989. Precambrian terranes of Benin-Nigeria and northeast Brazil and the Late Proterozoic South Atlantic fit. In Terranes in the circum-Atlantic Paleozoic orogens. Proterozoic South Atlantic fit. In Terranes in the
Geol. Soc. Amen, Spec. Paper, 230: 145-158.

Dantas E.L., Hackspacher PC., Kawashita K., Lafon J.M. 1991. Datações Rb-Sr nas ortoderivadas dos Grupos São Vicente/Caico - Provincia Borborema. In: Simp. Geol. Nordeste, 14, SBG, Recife, 248-252.

Hoffman PR, Kaufman A.L, Halverson G.P. 1998. Coming and Goings of Global Glaciations on a Neoproterozoic Tropical Platform in Namibia. Geol.. Soc. of America 8(5): 1-9.

Jardim oe Sa E.F. 1994. A FSe (Provincia Borborema, NE do Brasil) e o seu significado geodinâmico na cadeia Brasiliana/Pan-Afticana. Inst. de GeociSncias, Universidade de Brasilia, Tese de Doutoramento, 803p.

Jardim de Sa E.F. \& Salim J. 1980. Reavaliacao dos conceitos estratigraficos na região do Seridó (RN-PB). Miner. Metal., 80 (421): 16-28.

Jardim de Sa E.F., Fuck R.A., Macedo M.H.F., Peucat J.J., Kawashita K., Souza Z.S., Bertrand J.M. 1995. Pre-brasiliano orogenic evolution in the Seridó Belt, NE Brazil: Bertrand J.M. 1995. Pre-brasiliano orogenic evolution in the Serido Belt, NE Brazil:

Kaufman A.L \& Knoll A.H.(1995) Neoproterozoic variations in the C-isotopic composition of seawater: stratigraphic and biogeochemical implications. Prec. Research. 73: 27 94.

Kha L.C. , Sherman A.G, Narbonne G.M., Knoll A.M., Kaufman A.J. 1999. d³ C stratigraphy of the Proterozoic Bylot Supergroup, Baffin Islands, Canada: implications for regional lithostratigraphy correlations. Can. Journ. of Earth Sciences 36:313-332.
Knoll A.H., Hayes J.M., Kaufman A.J., Swett K., Lambert I.E. 1986. Secular variation in carbon isotope ratios from upper Proterozoic successions of Salvbard and East Greenland. Nature, 321: 832-838.

Legrand J.M., Liegeois J.P., Deutsch S. 1991. Datações U/Pb e Rb/Sr das rochas precambrianas da região de Caico. Reavaliação da definição de um embasamento arqueano. In: Simp. Geol. Nordeste, 14, SBG, João Pessoa, 276-279.

Melezhik V.A., Fallick A.E, Makarikhin V.V., Lyubtsov V.V. 1997. Links between Paleoproterozoic palaeogeography and rise and decline of stromatolites: Fennoscandian Shield. Prec. Research 82: 311-348.

Narbonne G.M., Kaufman A.J., Knoll, A.H. 1994. Integrated chemostratigraphy and biostratigraphy of the Windermere Supergroup, northwestern Canada: implications for Neoproterozoic correlations and the early evolution of animals. Geol. Soc. Amer. Bulletin 106:1281-1292.

Schidlowski M., Eichmann R., Junge C.E. 1976. Carbon isotope geochemsitry of the Precambrian Lomagundi carbonate province, Rhodesia. Geochim. Coschim. Acta, 40:449-455

Tucker M.E. 1983. Diagenesis, geochemistry, and origin of a Precambrian dolomite: the Rock Spring Dolomite, eastern California. Journ. Sedimentary Petrol., 53: 1097 1119 .

Van Schmus W.R., Brito Neves B.B., Hackspacher PC., Babinsky M. 1995. U/Pb and Sm/ Nd geochronologic studies of Eastern Borborema Province, northeastern Brazil: Initial conclusions. Jour. South Amer. Earth Sci., 8:267-288.

Van Schmus W.R., Dantas E., Brito Neves B.B., Hackspacher P.C., Babinsky M. 1996. Neoproterozoic age for Seridó Group, NE Borborema Province, Brazil. In: Cong. Bras. Geol. 39, SBG, Salvador, Anais 6:152-155.

Contribution IGC-128

Received March 1,2000 Accepted for publication May 3,2000 